\title{
The role of solid waste management as a response to urban flood risk in developing countries, a case study analysis
}

\author{
J. Lamond ${ }^{1}$, N. Bhattacharya ${ }^{2} \&$ R. Bloch ${ }^{3}$ \\ ${ }^{1}$ University of the West of England, Bristol, UK \\ ${ }^{2}$ University of Wolverhampton, Wolverhampton, $U K$ \\ ${ }^{3}$ GHK International, London, $U K$
}

\begin{abstract}
Solid waste management is a large and growing problem for countries in the developing world and is often a neglected aspect of urban management. However, poor waste management can contribute to the impact of urban flooding by blocking drainage, increasing debris and harbouring disease vectors. A review of the literature and analysis of case studies (both from the literature and from examples collected in the preparation of a global urban flood handbook) confirm that solid waste management is an emerging issue in flood risk management practice. Approaches to improve waste management included large municipal programmes and locally based community schemes. It was seen to be important that the management of waste is adopted as part of a wide integrated flood management programme. The research demonstrates that waste management can be an effective response to flood risk but, in order to remain successful, it requires that sufficient commitment and engagement can be mobilised in the long term.

Keywords: waste management, integrated flood management, urban flash flooding, developing countries, community response.
\end{abstract}

\section{Introduction}

The management of waste is a perennial problem in developed and developing countries [1-3] and it is an increasingly serious issue in respect of flood risk management [4] for the following main reasons: The poor disposal of waste frequently leads to blockages in drainage and watercourses $[5,6]$, this effectively 
reduces their capacity of storage and conveyance and leads to flooding [7, 8]; During a flood waste and other debris collected by floodwaters can cause increased damage to property and lead to higher flood losses [9, 10]; after a flood the deposition of waste can block access and be a source of toxins and breeding ground for disease. Floods can also have an impact on waste management systems [11] leading to leaching of toxins into groundwater. Thus the management of solid waste can be seen as one of the low regret options for reducing flood risk; contributing as it does to quality of life, health and development generally, while also lowering the impact of disasters [12, 13]. Low regret options are important for flood management in developing countries in particular because financial pressures render the integration of flood management with wider development goals especially critical.

Low priority is often accorded to the management of solid waste in developing countries for a number of reasons: waste management is frequently seen as a low status occupation with poor wages and therefore there may be a lack of relevant training and expertise [14]; low awareness of the health and sanitation implications of poor waste management can lead to an absence of pressure from civil society and therefore funds are diverted to other more high profile programmes; this lack of resources perpetuates the low status of waste management with no money to purchase equipment, train staff and develop disposal sites [14]. Poor wages can also encourage absenteeism. These factors not only result in inadequate collection and disposal of waste, they also tend to lead to concentration of resources in city centres and total neglect of the needs of informal settlements [4].

This paper therefore considers the role and awareness of waste management in flood risk reduction by reviewing the literature related to flood risk management and solid waste management. The review was focussed in particular on case studies that demonstrate the combination of waste management and flood risk reduction in developing countries. It aimed to address three research questions:

1. Is poor solid waste management a major contributor to flood risk management?

2. Is solid waste management an effective measure in flood risk reduction?

3. Are community based measures successful in improving the disposal of solid waste and reducing flooding?

\section{Literature review}

The method employed in the analysis is review of literature relating to case studies of flood risk involving poor solid waste management in the developing world. Case studies were identified from examples collected in the course of the preparation of an urban flood risk management handbook for the World Bank [14], from UN Habitat case studies [4] and from a general keyword search. More case studies were identified than could be included in the scope of this analysis, therefore case studies were selected on the basis of highest relevance to the 
research questions while ensuring examples from Asia, Latin America and Africa were included.

Solid waste management forms part of a complex urban management system that is interlinked [15] and frequently underfunded. This leads to the combination of poorly constructed and maintained drainage systems with inadequate waste management. These issues are not confined to the developing world [15] but they are more acutely felt in emerging economies where the rapid growth in urban populations are likely to result in massive increases in the demand for waste disposal and the breakdown, due to overloading, of existing functioning systems [15].

As noted above, in neighbourhoods with inadequate solid-waste management or drain maintenance, waste and vegetation can quickly clog conveyance systems and drains, leading to flooding. In particular solid waste can have an impact on the incidence of localized flooding with light rainfall. For instance, in Georgetown, Guyana this led to 29 local floods between 1990 and 1996 [16]. Residents in Tanzania also recognise that poor solid waste management blocking streams has exacerbated their flood risk [17].

The type and quantity of waste generated differs significantly between countries and within urban areas [5]. Industrialized countries and urban areas will tend to generate greater quantities of waste compared to developing countries and rural areas. In Asia the amount ranges from 0.5 kilogram per person per day in Nepal to more than 5 kilograms per person per day in Hong Kong [3]. In Latin America the range is said to be 0.5-1.0 kilogram/day per person [18]. Disposal and collection capacity also varies, for instance in cities like La-Paz, and Brasilia the total collection of solid waste is up to $90 \%$ on the other hand in Santiago the total collection is less than 57\% [18]. In Kumasi, Ghana, $40 \%$ of waste is said to end up in unauthorised garbage dumps and often the river [8]. Waste from upstream areas can also collect in cities as for example in Port-au-Prince in Haiti [6] and Managua in Nicaragua [14].

Waste management is comprised of three main steps: collection, transportation and disposal. Collection can be further divided into primary, secondary and tertiary stages reflecting the scale of the operation and resulting in the amalgamation of multiple waste streams into a body of waste materials that require disposal. The hierarchy of reduce, reuse, recycle, energy from waste disposal can be applied before collection, at the point of collection and during disposal to minimise the amount of waste eventually consigned to landfill. It has been observed that the engagement of populations in the process of waste reduction can be a highly effective mechanism to control waste. Therefore raising the awareness of residents regarding the benefits of waste reduction can be a first step in responsible waste management and flood risk reduction [2]. Community involvement and participation in community based approaches to the management of solid waste and improvement of drainage are often advocated. Lack of public participation is said to result in wasted municipal effort as, without understanding and awareness, locals will continue to dump their waste in drains [13]. 


\section{Case studies}

\subsection{Accra (Ghana)}

The 2007 floods in Accra, the capital city of Ghana, caused hundreds of people to leave their houses and move to safer locations [19]. Similar situations occurred in 1995, 1999, 2001, 2008 and 2011 causing havoc. Local flooding in Ghana is often attributed to blocked drainage caused by poor waste management [20]. However populations in Accra are hardly aware of the drainage issues associated with flooding and regard waste management as the role of the government [2]. It is observed that the population are not resilient and adaptive to the existing risk [21] and the level of preparedness, recovery and response is very low.

\subsection{Mumbai}

Mumbai in India is subject to many sources of flood risk including increased impervious areas and loss of storage within the city. Poor storm water drainage is, nevertheless, a major contributory factor to the severity of regular monsoon flooding [22]. Indiscriminate dumping of solid waste combined with storm water and municipal wastewater often clogs the drainage system resulting in coastal flooding and inundation during monsoon months [23]. In response to the 2005 flood the state put in place a ban on the sale and use of plastic bags. However this has not yet been effective due to lack of awareness and enforcement [1].

\subsection{Jakarta}

Jakarta, the capital of Indonesia, an urban metropolis of 27 million inhabitants is subject to the risk of flooding from the sea, rivers and intense rainfall. Subsidence of the city is increasing the risk to Jakarta and massive urbanisation has led to reduction of storage areas for water throughout the city. Major channelization of drainage through and around the city was designed to convey flows representing the 25 year flood event. However, silting and poor waste management has resulted in the reduction of the channel capacity to a one in five year level. Although waste collection was privatised in some districts of Jakarta in the late 1980s [24], this initiative covered only middle to high income residents and the slow disposal of collected waste still results in large rubbish dumps in informal areas [25]. Local community based drain clearance, waste recycling and removal schemes have been successful in generating employment and raising awareness of the importance of drainage, but the scale of the urban waste stream and the carriage of waste from upstream into the city means that the local efforts are not effective in reducing flood risk [26].

\subsection{Bamako}

Bamako, the capital of Mali, has a population of approximately one million with roughly half residing in informal settlements. In 1999 flash flooding throughout 
Bamako caused death and destruction and analysis showed that poor waste disposal was a significant contributory factor. Consequently a four year project was aimed at improving the management of storm water and solid waste in one of the worst affected districts of the city. Among other things the project set up improved waste collection: eight collection routes, each served by a collection team using tractor-trailers, with disposal at a nearby landfill. The scheme also created local employment for refuse collectors. Stakeholder participation, combined with a comprehensive planning framework, was used for the first time in the city. This helped to build consensus and increase capacity within Non Governmental Organisations and Community based organisations. Channel volume was restored and flood risk reduced and Bamako has not experienced a similar flood disaster since 1999, partly as a result of these measures [27]. However, the City of Bamako in general still faces big challenges in waste disposal as responsibility for funding activities is not clear and the final disposal sites are inadequate. The planned landfill site $30 \mathrm{~km}$ outside the city has not yet been constructed [4].

\subsection{Maputo}

Maputo, the capital of Mozambique, houses $45 \%$ of the total Mozambican urban population, $50 \%$ of which is considered to live below the poverty line. During the 2000 flood 70 percent of flood deaths were in urban areas near Maputo, mainly in the cities of Xai-Xai and Chokwe [28]. Maputo is highly vulnerable to flooding from sea level rise, fluvial and pluvial flooding. In Maputo risk has been reduced by construction of improved drainage systems on the border of the Mafala district. The introduction of a "garbage tax" to finance improvements in solid waste management was administered. The government negotiated public service contracts that institutionalized the primary collection as a free-of-charge public service for all residents [29]. However, despite this investment, during the 2010 floods solid waste blocked the new channels and emergency clearance was necessary. Flood risk mitigation efforts in Mozambique now include many nonstructural measures such as preparedness education that stresses the need to keep drainage clear [14].

\subsection{Marikina}

In the Philippines, regeneration of the Marikina River was undertaken, to enhance the local area and reduce flooding. After clearing the river the municipality introduced a strict waste collection policy which forbade dumping of garbage outside of houses except on collection days. The policy is enforced via penalties for non-compliance. The river is much more attractive as a result and flooding has been reduced, however success of this policy is limited by the influx of waste from settlements further upstream [30]. 


\subsection{Cotonou}

Cotonou with a population of about 700,000 is Benin's largest urban centre and major port. Large areas of commercial and residential importance are at risk from sea-level rise and storm surges. In addition the drainage system is inadequate and poor solid waste management contributes to drainage problems, worsening the impact of flooding [31]. Within the informal settlements waste management is not provided by the municipal authority, centralisation has ensured that waste collection is concentrated in the city centre. In the 1990s Pr A.P.E. The "Programme Assainissement et Protection de l'Environment" commenced in the Sainte-Rita municipality. This participatory programme trained and employed youths and women to collect and recycle waste and a nascent private sector arose backed by a community bank [4]. Unfortunately many of these firms subsequently went out of business because of the low fees.

\subsection{Lagos}

Lagos is a megacity in Nigeria, West Africa of about 10 million inhabitants. The city is low lying and highly prone to flood from sea-level rise and storm surges. Apart from that in the rainy season, intense rainfall results in flooding as matter of course. Drainage systems are in general inadequate and often blocked due to poor waste management practice. Interviews in the informal settlements near the coast revealed that flooding was one of the most serious problems they faced and confirmed that poor waste management and clogged drains were one of the major causes of the flooding [32].

Awareness of solid waste issues was seen to be high in Lagos, but in 2008 there were few community initiatives to clear blocked channels. Now there is a city-wide strategy in place and Lagos has recently been subject to a greatly improved waste management programme [33] including street advocacy and highly visible workers to create awareness.

\subsection{Managua}

Flooding in Managua, the capital of Nicaragua, is greatly increased by the blocking of the many watercourses that run through this dispersed urban area. The population of approximately two million [34] is sited on steep rugged terrain and subject to earthquakes and flooding. The recent population growth has led to deficits in basic facilities and services and weak urban governance resulting in serious shortcomings in the refuse collection service [1]. To address the issue in 1980 a system of micro-dams was established with the dual purpose of attenuating floods and retaining refuse. Over 16 dams have been constructed Figures show that they extract in excess of $500 \mathrm{~m}^{3}$ of sediment from the river system [34]. However, flooding is still a yearly event in several neighbourhoods of Managua due to the lack of a drainage master plan and poor urban planning. The lack of flood awareness means that settlements still grow into the most risky areas. Recent initiatives in solid waste management [1] may lead to improved flood risk, athough the driving force behind the initiatives is not flood reduction. 


\subsection{Mexico City}

Mexico City, Mexico has been subject to greatly increased incidence of flash flooding over the $20^{\text {th }}$ century. The high urban density ensures that intense rainfall events, such as occurred in 2006, cause massive flooding. Informal settlements are particularly vulnerable. The area is at risk of multiple hazards as steep terrain can result in landslides and loss of life and the accumulation of trash and debris in the inadequate drainage system worsen the impacts and make recovery slower [36].

\subsection{Georgetown}

In Georgetown, Guyana, an assessment of the drivers for vulnerability of neighbourhoods to flooding evaluated the main causes in four wards [16]. Drainage issues were identified by residents of all four wards because drainage channels were blocked by a combination of overgrowth, silt and waste. The study concluded that the clearance of drainage by residents in one ward had contributed to the reduction of flooding in this area. In other areas lack of municipal waste collection and no community action had resulted in continued flooding. Residents of these areas took other approaches to minimise damage such as moving out of the ground floor.

\section{Results}

The case studies (summarised in table 1) reinforced existing perceptions in the flood management literature regarding the importance of solid waste management in reducing flood risk. However these examples also highlighted the fact that no single approach to waste management was universally successful in practice.

Literature demonstrates that poor waste management is a perennial problem that is set to get worse with the rapid expansion of urban areas in the developing world and the inability of municipalities to resource the necessary waste collection. The case studies confirmed that solid waste management is a major contributory factor to urban flooding across the globe with examples from Asia, Africa and Latin America. For many of the examples blocked drainage is particularly implicated in localised flash flooding; but solid waste was also seen to worsen the impact of all types of floods.

The case studies illustrate the fact that the impact of poor solid waste management is experienced very keenly by residents of informal settlements that are often outside the control of municipal authorities. These residents are also more vulnerable to the impacts of flooding and less able to cope with it: therefore improvements in solid waste management can have a disproportionate effect on reducing vulnerability.

In several of the case studies informal settlements were not served by municipal authority collection and disposal schemes. In such settlements a combination of private enterprise and community participation was seen to be 
Table 1: $\quad$ Summary of main features of case studies.

\begin{tabular}{|c|c|c|c|c|}
\hline $\begin{array}{l}\text { Case } \\
\text { study }\end{array}$ & $\begin{array}{l}\text { Problem } \\
\text { identified }\end{array}$ & $\begin{array}{l}\text { Community } \\
\text { awareness }\end{array}$ & Municipal action & $\begin{array}{c}\text { Community } \\
\text { action }\end{array}$ \\
\hline Bamako & $\begin{array}{l}\text { Poor waste } \\
\text { management a } \\
\text { major factor in } \\
1999 \text { flood }\end{array}$ & $\begin{array}{l}\text { Awareness was } \\
\text { raised during the } \\
\text { programme }\end{array}$ & $\begin{array}{l}\text { Structural drainage } \\
\text { improvement was } \\
\text { carried out }\end{array}$ & $\begin{array}{c}\text { Local waste } \\
\text { collection system } \\
\text { set up. Disposal } \\
\text { still a problem }\end{array}$ \\
\hline Accra & $\begin{array}{c}\text { Blockage of } \\
\text { drainage causes } \\
\text { flooding }\end{array}$ & $\begin{array}{l}\text { Residents not } \\
\text { aware }\end{array}$ & $\begin{array}{l}\text { Authorities appear } \\
\text { overwhelmed }\end{array}$ & $\begin{array}{l}\text { Residents regard } \\
\text { it as the role of } \\
\text { the government }\end{array}$ \\
\hline Cotonou & $\begin{array}{c}\text { Indiscriminate } \\
\text { dumping of waste }\end{array}$ & $\begin{array}{l}\text { Yes and some } \\
\text { have taken } \\
\text { action }\end{array}$ & $\begin{array}{c}\text { Peripheral areas } \\
\text { neglected as the } \\
\text { focus is on the city } \\
\text { centre }\end{array}$ & $\begin{array}{l}\text { Locals trained to } \\
\text { collect and gain } \\
\text { revenue from } \\
\text { waste }\end{array}$ \\
\hline Maputo & $\begin{array}{l}\text { Flooding caused } \\
\text { by inadequate } \\
\text { drainage in the } \\
\text { city }\end{array}$ & $\begin{array}{l}\text { Awareness low } \\
\text { but being } \\
\text { targeted by } \\
\text { education } \\
\text { programmes }\end{array}$ & $\begin{array}{l}\text { Some urban } \\
\text { drainage } \\
\text { improvement } \\
\text { programmes in } \\
\text { Maputo }\end{array}$ & $\begin{array}{l}\text { Communities still } \\
\text { dump rubbish in } \\
\text { drains, causing } \\
\text { major problems } \\
\text { in } 2010 \text { flood }\end{array}$ \\
\hline Lagos & $\begin{array}{l}\text { Flooding due to } \\
\text { blocked drainage }\end{array}$ & $\begin{array}{l}\text { High awareness } \\
\text { in community }\end{array}$ & $\begin{array}{c}\text { New city wide } \\
\text { strategy of waste } \\
\text { disposal }\end{array}$ & $\begin{array}{c}\text { Very few } \\
\text { community } \\
\text { initiatives }\end{array}$ \\
\hline Marikina & $\begin{array}{l}\text { Flooding partly } \\
\text { due to waste } \\
\text { clogging the river }\end{array}$ & $\begin{array}{c}\text { Residents made } \\
\text { aware by the } \\
\text { programme }\end{array}$ & $\begin{array}{l}\text { River dredging and } \\
\text { penalties for } \\
\text { dumping }\end{array}$ & $\begin{array}{l}\text { Residents comply } \\
\text { but waste still } \\
\text { arrives from } \\
\text { further upstream }\end{array}$ \\
\hline Jakarta & $\begin{array}{l}\text { Blocked channels } \\
\text { cause widespread } \\
\text { flooding }\end{array}$ & $\begin{array}{l}\text { Residents aware } \\
\text { of the problem }\end{array}$ & $\begin{array}{l}\text { Government plans } \\
\text { to dredge channels } \\
\text { but hampered by } \\
\text { informal } \\
\text { settlements }\end{array}$ & $\begin{array}{l}\text { Local community } \\
\text { based schemes } \\
\text { successful but } \\
\text { waste is carried } \\
\text { from upstream } \\
\text { areas }\end{array}$ \\
\hline Mumbai & $\begin{array}{l}\text { Plastic bags } \\
\text { blamed for } \\
\text { flooding }\end{array}$ & Poor awareness & $\begin{array}{l}\text { Ban on use of } \\
\text { plastic bags }\end{array}$ & $\begin{array}{c}\text { Poor compliance } \\
\text { with ban }\end{array}$ \\
\hline Guyana & $\begin{array}{c}\text { Clogged and } \\
\text { inadequate } \\
\text { drainage leading } \\
\text { to flooding }\end{array}$ & $\begin{array}{l}\text { Identified by } \\
\text { residents as } \\
\text { important. }\end{array}$ & $\begin{array}{l}\text { Authorities have } \\
\text { other priorities }\end{array}$ & $\begin{array}{l}\text { In one ward CBO } \\
\text { had cleared } \\
\text { drains, this ward } \\
\text { had not flooded }\end{array}$ \\
\hline $\begin{array}{l}\text { Mexico } \\
\text { City }\end{array}$ & $\begin{array}{l}\text { Waste blocks } \\
\text { drains and leads } \\
\text { to flash flooding }\end{array}$ & $\begin{array}{l}\text { Appears to be } \\
\text { low awareness }\end{array}$ & $\begin{array}{l}\text { Programmes focus } \\
\text { on other priorities }\end{array}$ & $\begin{array}{c}\text { No evidence of } \\
\text { community } \\
\text { action }\end{array}$ \\
\hline Managua & $\begin{array}{l}\text { Waste in the } \\
\text { rivers worsen } \\
\text { flooding }\end{array}$ & $\begin{array}{c}\text { Awareness is } \\
\text { poor }\end{array}$ & $\begin{array}{l}\text { Network of micro } \\
\text { dams to collect } \\
\text { rubbish and silt }\end{array}$ & $\begin{array}{c}\text { Low compliance, } \\
\text { flooding still an } \\
\text { annual event }\end{array}$ \\
\hline
\end{tabular}

the only way forward to improve waste management. Communities can generate employment opportunities and revenue by sorting and recycling waste rather than dumping it.

Another feature of the case studies is that interventions in drainage and solid waste by governments and NGOs were often effective in the short term but their 
effectiveness reduced in the longer term as the impetus faded and systems were not maintained. This tendency for systems to fall into disuse may be partly compounded by the fact, also seen in the examples here, that locally based schemes cannot wholly address the blocked drainage problems, as new waste is conveyed from upstream areas that are out of the control of the local activists.

\section{Conclusions}

1. Poor solid waste management contributes to urban flooding across the globe and, as urban populations increase, is likely to be an increasingly important factor.

2. The control of solid waste within areas at risk of flooding has the potential to reduce risk by minimising the amount of waste blocking drainage channels. However local programmes are limited in their effectiveness as solid waste is often carried downstream and residents do not reap the benefit of reducing their own waste.

3. Reduced accumulation of waste in general will reduce the environmental impact of flooding and has multiple other benefits to health and wellbeing.

4. Engagement of communities in risk reduction is helpful in increasing resources and in generating the necessary awareness and motivation to reduce dumping. Measures implemented without community participation are often undermined by poor waste disposal habits.

5. There is a need to educate the public to bring change in their attitude towards dumping and reduction of waste. Disapproval of undesirable activities and tackling apathy towards appropriate operation and maintenance of existing infrastructure may bring forth good user practices.

6. Community based measures need to be a part of a wider waste management plan in order to make a permanent scalable difference to the amount of waste dumped in cities and by extension to flood risk.

7. Flood risk reduction via solid waste management can be effective as part of an integrated flood management plan, however, it requires long term, ongoing, commitment from municipalities and communities.

\section{References}

[1] UN Habitat, Solid waste management in the world's cities, Water and Sanitation in the Worlds Cities 2010, London/Washington: Earthscan, 2010.

[2] Sam. P.A. Are the Municipal Solid Waste Management Practices Causing Flooding During the Rainy Season in Accra, Ghana, West Africa, online [accessed 09/05/2011], Modern Ghana. 2009.

[3] Hoornweg, D., and Thomas, L. What a waste: solid waste management in Asia. IN REGION, E. A. A. P. (Ed.) Urban Development sector unit working paper series no. 1. Washington DC, The World Bank.1999. 
[4] UN HABITAT, The State of African Cities 2010: Governance, Inequality and Urban Land Markets. Nairobi, UN Habitat. 2010.

[5] Muñoz-Cadena, C.E., Arenas-Huertero, F.J. and Ramón-Gallegos, E. Comparative analysis of the street generation of inorganic urban solid waste (IUSW) in two neighborhoods of Mexico City, Waste Management, 29(3): p.1167-1175. 2009.

[6] Bras, A., Berdier, C., Emmanuel, E. and Zimmerman, M., Problems and current practices of solid waste management in Port-au-Prince (Haiti), Waste Management, 29(11): p. 2907-2909. 2009.

[7] Marfai, M.A., Urban coastal flooding and risk management (an overview of Jakarta and Semarang City. Presentation in the consultation workshop Preparation of a Global Handbook for Urban Flood Risk Management, Jakarta, May 25-6. 2011.

[8] Appiah, D.O. The Dilemma of Poverty and Safety: The Case of Urban Flooding in the Aboabo River Basin, In Jha, A. Lamond, J., and Bloch, R. Cities and Flooding: A Guide to Integrated Urban Flood Risk Management for the 21st Century, Washington, GFDRR/World Bank. 2012.

[9] Nicholas, J. and Proverbs, D. Benchmarking the assessment of flood damaged domestic properties. London. Royal Institute of Chartered Surveyors. 2002.

[10] Chen, J., Tsai, H., Hsu, P. and Shen, C. 2007, Estimation of waste generation from floods, Waste Management. 27(12): p. 1717-1724. 2007.

[11] Pilapitiya, S., Vidanaarachchi, C. and Yuen, S., Effects of the tsunami on waste management in Sri Lanka, Waste Management, 26(2): p. 107-109. 2006.

[12] Jha, A. Lamond, J., and Bloch, R. Cities and Flooding: A Guide to Integrated Urban Flood Risk Management for the 21st Century, Washington, GFDRR/World Bank. 2012.

[13] ADPC. Mainstreaming disaster risk reduction, Urban Governance and Community Resilience Guides, no 4. ADPC, 2010.

[14] Jha, A., Lamond, J., Bhattacharya, N., Lopez, A., Bird, A., Proverbs, D., Davies, J., Papachristodolou, N. and Bloch, R. Five feet high and rising, Cities and Floods in the 21st Century. Policy Research Working Paper Series 5648. Washington DC, World Bank. 2011.

[15] Ruth, M., Coelho, D., Understanding and managing the complexity of urban systems under climate change, Climate Policy 7(4): p. 317-336, 2007.

[16] Pelling M., What determines vulnerability to floods: a case study in Georgetown, Guyana, Environment and Urbanization, 9(1): p. 203-226. 1997.

[17] Dodman, D., Kibona, E., and Kiluma, L., Tomorrow is too late: Responding to Social and Climate Vulnerability in Dar es Salaam, Tanzania. Case study prepared for Cities and Climate Change: Global Report on Human Settlements 2011, UN-habitat. 2011. 
[18] USAID. Environmental issues and best practices for solid waste management, Environmental guidelines for the USAID Latin America and Caribbean Bureau. 2006.

[19] Concern universal. Concern Universal Flood Relief in Northern Ghana September 2007. http://www.concernuniversal.org/index.php?/where_we_work/ghana/flood relief_in_north_ghana,_september_2007. Date accessed 19.04.2011.2007.

[20] Boadi K, Kuitunene M. Municipal Solid Waste Management in the Accra Metropolitan Area, Ghana. The Environmentalist. 2003; 23: p. 211-218, 2003.

[21] Ahadzie, D. K., and Proverbs, D. G. Flooding and Post Flooding Response Strategies in Ghana. WIT Transactions on Ecological Environment, 33: p. 281-291, 2010.

[22] Gupta, K., Urban flood resilience planning and management and lessons for the future: a case study of Mumbai, India, Urban Water Journal, 4(3): p. 183-194. 2007.

[23] Murthy, R. C., Rao, Y. R. and Inamdar, A. B. Integrated coastal management of Mumbai metropolitan region, Ocean \& Coastal Management, 44: p.355-369. 2001.

[24] Klundert, A., and Lardinois, I. Community and Private (formal and informal) sector involvement in municipal solid waste management in developing countries, Background Paper presented at the Ittingen Workshop, Ittingen, Switzerland April 10/12. 1995.

[25] Cointreau-Levine, S. Private sector participation in municipal solid waste services in developing countries. Vol. 1. The formal sector. Urban Management Programme Discussion Paper No. 13. World Bank. Washington, United States, 1994.

[26] Mercycorps, Community Based Flood Risk Management Initiatives. Learning from flood risk reduction projects in Jakarta Presentation in the consultation workshop Preparation of a Global Handbook for Urban Flood Risk Management, Jakarta, May 25-6. 2011.

[27] Setchell, C. A., Multi-sector disaster risk reduction as a sustainable development template, the Bamako flood hazard mitigation project. Monday Developments, Interaction. 2008.

[28] UN-HABITAT Bamako - Using Partnerships to Support Environmental Management.

http://ww2.unhabitat.org/programs/uef/cities/summary/bamako.htm. 2007.

[29] Kruks Wisner, G. After the Flood: Crisis, Voice and Innovation in Maputo's Solid Waste Management Sector. Boston: Massachusetts Institute of Technology, 2006.

[30] ADPC. Flood Disaster Mitigation and River Rehabilitation by Marikina City, Philippines. Safer Cities 22: Case studies on mitigating disasters in Asia and the Pacific. 2008.

[31] Dedehouanou, H., Coping with house waste management in Cotonou, Environment and Urbanization, 10(2), p.191-208. 1998. 
204 Flood Recovery Innovation and Response XI

[32] Adelekan, IN Cities and climate change Global report on human settlements 2011, Washington/London Earthscan. 2011.

[33] Oresanya, O. Integrated Waste Management Waste Collection \& Transportation System Paper presented at the C40 Summit Speaking Session 1st June, Curitiba, Brazil. 2011

[34] Tucci, C. E. M. Urban Flood Management. WMO and Capnet. 2007.

[35] Espinosa, M. Policy and institutional aspects of water resources management in Nicaragua - The case of Managua. Masters Thesis, Lund Universit: Lund, 2000.

[36] Ibarrarán, M. Climate's long-term impacts on Mexico's city urban infrastructure, Unpublished case study prepared for the Global Report on Human Settlements 2011, www.unhabitat.org/grhs/2011 cited in UN Habitat (2011) Cities and climate change Global report on human settlements 2011, Washington/London Earthscan, 2010. 